\title{
ANALISIS TRANSAKSI AKAD SALAM DALAM JUAL BELI ONLINE
}

\author{
Aly Akbar ${ }^{1}$, Moch. Cahyo Sucipto ${ }^{2}$ \\ ${ }^{1}$ Pascasarjana UIN Sunan Gunung Djati Bandung \\ ${ }^{2}$ Prodi Perbankan Syariah STIES Indonesia Purwakarta \\ ${ }^{1}$ akbar.aly@gmail.com \\ ${ }^{2}$ cahyosucipto@gmail.com
}

\begin{abstract}
Intisari- Berdasarkan pada pembahasan sebelumnya, dan merujuk pada hasil penelitian yang telah dilakukan maka dapat disimpulkan hal-hal berikut: Skema akad salam dalam jual beli online terdapat muslam (pembeli), muslam ilaih (penjual), muslam fihi (objek barang) dan juga sighat (ijab dan qabul); Akad salam dalam jual beli online, telah memenuhi rukun dan syarat sah yang berlaku dalam hukum fiqh, dan sesuai fatwa DSN MUI tahun 2000. Melihat dari proses dan skema akad salam dalam jual beli online ini adalah bentuk yang diperbolehkan; Mekanisme dalam transaksi akad salam pada jual beli online ini memudahkan para konsumen dalam melakukan transaksi secara online.
\end{abstract}

Kata kunci - Akad Salam, Jual Beli Online.

Abstract - Based on the previous discussion, and referring to the results of the research that has been done, it can be concluded the following points: The greeting contract scheme in buying and selling online there is muslam (buyer), muslam ilaih (seller), muslam fihi (object of goods) and also sighat ( consent and qabul); The contract of greeting in buying and selling online, has fulfilled the rules and legal requirements that apply in the law of fiqh, and is in accordance with the DSN MUI fatwa in 2000. Looking at the process and scheme of the agreement to sell online this is a permissible form; The mechanism in the transaction of the contract to buy and sell online makes it easy for consumers to make transactions online.

Keywords - Greetings, Buy and Sell Online.

\section{Pendahuluan}

Manusia merupakan mahluk sosial, dimana manusia berinteraksi (bermasyarakat, tolong menolong) untuk memenuhi kebutuhan hidup dan mencapai tujuan hidup yang lebih maju. Ajaran Islam yang dibawa Nabi Muhammad SAW ini memiliki keunikan tersendiri, dimana dalam ajaran tersebut tidak hanya bersifat komprehensif, tapi juga bersifat universal . Komprehensif berarti mencangkup seluruh aspek kehidupan, baik ritual, maupun sosial (hubungan antara sesama makhluk). Sedangkan Universal bisa diterapkan kapan saja, hingga hari akhir.

Landasan ajaran Islam Al-Qur'an dan Al-Hadis memiliki daya jangkau dan daya atur yang secara universal dapat dilihat dari sisi teksnya yang selalu pas untuk diimplementasikan dalam wacana kehidupan aktual, misalnya daya jangkau dan daya atur dalam masalah perekonomian. Ekonomi Islam mempunyai tujuan memberikan keselarasan bagi kehidupan di dunia. Hal ini karena nilai Islam tidak hanya untuk kehidupan muslim, tetapi untuk seluruh makhluk hidup di muka bumi. Ekonomi Islam menjadi rahmat seluruh alam yang tidak terbatas oleh ekonomi, sosial, budaya, dan politik dari bangsa. Ekonomi Islam mempunyai tujuan memberikan keselarasan bagi kehidupan di dunia. Hal ini karena nilai Islam tidak hanya untuk kehidupan muslim, tetapi untuk seluruh makhluk hidup di muka bumi. Esensi proses ekonomi Islam adalah penenuhan kebutuhan manusia yang berlandaskan nilai-nilai Islam untuk mencapai pada tujuan agama (Falah). Ekonomi Islam menjadi rahmat untuk seluruh alam yang tidak terbatas oleh ekonomi, sosial, budaya, dan politik dari bangsa.

Tidak banyak yang dikemukakan dalam Al-Quran tentang ekonomi Islam, melainkan hanya prinsip-prinsip yang mendasar. Al-Quran dan Sunnah banyak membahas perilaku kaum muslim sebagai produsen, konsumen, dan pemilik modal, tetapi hanya sedikit tentang sistem ekonomi . Syariah Islam sebagai suatu syariah yang dibawa oleh rasul terakhir, mempunyai keunikan tersendiri. Sayariah ini bukan saja menyeluruh atau komprehensif, tetapi juga universal. Karakter istimewa ini diperlukan sebab tidak akan ada syariah lain yang dating untuk menyempurnakannya. Komprehensif berarti syariah Islam merangkum seluruh aspek kehidupan, baik ritual (ibadah) maupun sosial (muamalah). Ibadah diperluakan untuk menjaga ketaatan dan keharmonisan hubungan manusia dengan Khaliq-nya. Ibadah juga merupakan sarana untuk mengingatkan secara kontinu tugas manusia sebagai khalifahNya dimuka bumi ini. Adapun muamalah diturunkan untuk menjadi rules of the game atau aturan main manusia dalam kehidupan sosial. kelengkapan sistem muamalah yang disampaikan Rasulullah SAW.

Dari segi bahasa, muamalah berasal dari kata aamala, yuamilu, muamalt yang berarti perlakuan atau tindakan terhadap orang lain, hubungan kepentingan. Kata-kata semacam ini adalah kata kerja aktif yang harus mempunyai dua buah pelaku, yang satu terhadap yang lain saling melakukan pekerjaan secara aktif, sehingga kedua pelaku tersebut saling menderita dari satu terhadap yang lainnya.

Muamalat berbeda dengan ibadah. Dalam ibadah, semua perbuatan dilarang kecuali yang diperintahkan. Oleh karena itu, semua perbuatan yang dikerjakan harus sesuai dengan tuntunan yang diajarkan oleh Rasulullah SAW. Sebaliknya, dalam muamalat, semuanya boleh kecuali yang dilarang. Muamalat atau hubungan dan pergaulan antara sesama manusia dibidang harta benda merupakan urusan duniawi, dan pengaturannya diserahkan kepada manusia itu sendiri. Oleh karena itu, semua bentuk akad dan berbagai cara transaksi yang dibuat oleh manusia hukumnya sah dan dibolehan, asal tidak bertentangan dengan ketentuan-ketentuan umum yang ada dalam syara'. 
Aspek perekonomian merupakan suatu hal yang sangat penting, dimana posisi ini menentukan akan kesejahteraan manusia semuanya. Akad salam atau pesanan erat kaitannya dengan akad jual beli. Bahkan menurut Imam'Alauddin AlKasani ," salam itu adalah jual beli “. Dalam pembahasan mengenai macam-macam jual beli, ditinjau dari segi hubungan dengan objeknya, jual beli terbagi kepada empat bagian, yaitu, Jual beli mutlaq, Jual beli muqayadhah, Jual beli sharf, dan jual beli salam. Dengan demikian, salam merupakan salah satu bagian dari bentuk jual beli. Oleh karena itu, pembahasannya masih berdekatan dengan akad jual beli, dan ditempatkan setelah khiyar yang juga masih berkaitan dengan akad jual beli.

Salam secara etimologi artinya pendahluan, dan secara muamalah adalah penjualan suatu barang yang disebutkan sifat-sifatnya sebagai persyaratan jual beli dan barang yang dibeli masih dalam tanggungan penjual, dimana syaratnya ialah mendahulukan pembayaran pada waktu akad. Salam adalah akad jual beli barang pesanan antara pembeli dan penjual dengan pembayaran dilakukan di muka pada saat akad dan pengiriman barang dilakukan pada saat akhir kontrak. Barang pesanan harus jelas spesifikasinya.

Pengertian salam menurut istilah dikemukakan oleh Kamaliddin bin Al-hammam dari mazhab Hanafi sebagai berikut "Sesungguhnya pengertian salam menurut syara' adalah jual beli tempo dengan tunai”. Dari definisi yang dikemukakan oleh ulama mazhab tersebut dapat diambil intisari bahwa salam adalah salah satu bentuk jual beli di mana uang harga barang dibayarkan secara tunai, sedangkan barang yang dibeli belum ada, hanya sifat-sifat, jenis, dan ukurannya sudah disebutkan pada waktu perjanjian dibuat.

Seiring dengan berkembangnya kemajuan zaman, di era modern seperti ini semua membutuhkan teknologi yang mana dalam jual beli pun menggunakan teknologi elektronik, serta kemajuan IPTEK (ilmu pengetahuan dan teknologi), maka dalam hal ini mengarah pada suatu titik, yaitu membentuk dan mewujudkan perubahan terhadap pola kehidupan masyarakat, tidak terkecuali dalam bidang ekonomi, yaitu tentang suatu perdagangan. Dengan adanya teknoligi maka kita bisa melakukan apa pun, hanya dengan pertukaran data saja kita bisa melakukan jual beli secara jarak jauh (E-commerce / non face).

Kehadiran akad salam dalam jual beli online ini memudahkan para pembeli, mereka tinggal memesan barang menggunakan media Gadget yang terhubung melalui internet. Sehubungan dengan maraknya jual beli menggunakan akad salam pada jual beli online, munculah berbagai situs jual beli online. Dengan menawarkan berbagai kebutuhan para konsumen, dengan persyaratan mudah, proses cepat dan pengiriman ke seluruh penjuru Indonesia. Keberhasilan tersebut di lihat dari banyaknya para pengguna aplikasi jual beli online, banyaknya Produk yang ditawarkan, dengan harga yang relative terjangkau oleh semua kalangan.

Bukalapak menjadi situs paling banyak dikunjungi di Indonesia alias no.1 dengan pengunjung paling banyak di Indonesia Dilihat dari kesuksesannya maka, Bukalapak menjadi situs dengan pendapatan per hari paling tinggi di Indonesia, merupakan situs jual beli online yang aman, mudah dan $100 \%$ terpercaya dengan Bukalapak Payment System. Jika Bukalapak.com dibandingkan dengan Detik.com yang menjadi situs dengan jumlah pengunjung paling banyak maka secara kuantitas jumlah pengunjung tiap harinya, Bukalapak masih kalah jauh dari Detik. Karena pengunjung Detik.com tiap harinya sekitar 694.634 sedangkan pengunjung Bukalapak hanya 250.434. Akan tetapi situs Bukalapak yang termasuk situs yang paling muda dibandingkan dengan situs-situs yang lain mampu menjadi situs Indonesia dengan pendapatan tertinggi di Indonesia. Mungkin faktor penawaran iklan yang tinggi di Bukalapak menjadi salah satu faktor mengapa Bukalapak mampu mendapatkan pendapatan yang tinggi. Angka 29.770 USD jika dirupiahkan dengan kurs 13.000 maka pendapatan Bukalapak tiap harinya mencapai Rp 387.010.000,-Berdasarkan latar belakang tersebut maka penulis merasa tertarik untuk menulis mengenai Analisis transaksi akad salam dalam jual beli online.

\section{Metodologi}

Menurut Denzin dan Licoln Jenis pendekatan yang digunakan dalam penelitian ini adalah dengan metode deskriptif kualitatif. Penelitian deskriptif adalah penelitian yang berusaha mendeskripsikan suatu gejala, peristiwa, kejadian yang terjadi saat sekarang. Penelitian deskriptif memusatkan perhatian pada masalah aktual sebagaimana adanya pada saat penelitian berlangsung. Melalui penelitian deskriptif, peneliti berusaha mendeskripsikan peristiwa dan kejadian yang menjadi pusat perhatian tanpa memberikan perlakuan khusus terhadap peristiwa tersebut. Variabel yang diteliti bisa tunggal (satu variabel) bisa juga lebih dari satu variabel. Kata kualitatif menyiratkan penekanan pada proses dan makna yang tidak dikaji secara ketat atau belum diukur dari sisi kuantitas, jumlah, intensitas, atau frekuensinya. Pendekatan kualitatif adalah suatu proses penelitian dan pemahaman yang berdasarkan pada metodologi yang menyelidiki suatu fenomena sosial dan masalah manusia. Pada pendekatan ini, peneliti menekankan sifat realitas yang terbangun secara sosial, hubungan erat antara peneliti dan subjek yang diteliti.

Menurut creswell Penelitian kualitatif sebagai suatu gambaran kompleks, meneliti kata-kata, laporan terinci dari pandangan responden, dan melakukan studi pada situasi yang alami. Penelitian kualitatif merupakan riset yang bersifat deskriptif dan cenderung menggunakan analisis dengan pendekatan induktif. Proses dan makna (perspektif subjek) lebih ditonjolkan dalam penelitian kualitatif. Landasan teori dimanfaatkan sebagai pemandu agar fokus penelitian sesuai dengan fakta dilapangan. Selain itu, landasan teori juga bermanfaat untuk memberikan gambaran umum tentang latar penelitian dan sebagai bahan pembahasan hasil penelotian. Terdapat perbedaan mendasar antara peran landasan teori dalam penelitisn kuanitatif dan kualitatif. Dalam penelitian kuantitatif, penelitian berangkat dari teori menuju data, dan berakhir pada penerimaan atau penolakan terhadap teori yan digunakan. Adapun dalam penelitian kualitatif, penelitian bertolak dari data, memanfaatkan teori yang ada sebagai bahan penjelas, dan berfikir dengan suatu "teori".

Penelitian kualitatif dilakaukan pada kondisi alamiah dan bersifat penemuan. Dalam penelitian kualiatif, peneliti merupakan instrument kunci. Oleh karena itu, peneliti harus memiliki bekal teori dan wawasan yang luas jadi bisa bertanya, menganalisis, dan mengkonfirmasi objek yang diteliti menjadi lebih jelas. Penelitian ini lebih menekankan pada makna dan terikat nilai. Penelitian kualitatif digunakan jika masalah belum jelas, mengetahui makna yang tersembunyi, untuk memahami interaksi sosial, mengembangkan teori, memastikan kebenaran data, dan meneliti sejarah perkembangan.

Metode penelitian kualitatif sering disebut metode penelitian naturalistic karena penelitiannya dilakukan pada kondisi yang alamiah (natural setting), disebut juga sebagai metode etnographi, karena pada awalnya metode ini lebih banyak 


\section{EKSISBANK Vol. 2 No. 2 Desember 2018}

digunakan untuk penelitian bidang antropologi budaya, disebut sebagai metode kualitatif, karena data yang terkumpul dan analisanya lebih bersifat kualitatif. Pendekatan ini memungkinkan peneliti mendapatkan data yang lebih banyak dan akurat sehingga peneliti dapat memahami bagaimana Transaksi Akad Salam pada Jual Beli Online.

Dalam penelitian ini penulis membagi sumber data menjadi dua macam, yaitu : Sumber Data Primer, adalah sumbersumber yang memberikan data langsung dan dijadikan rujukan pokok dalam penelitian.Menurut buku serial Ekonomi dan Bisnis Islam. Sumber Data Sekunder, adalah sumber data yang diperoleh peneliti secara tidak langsung. Adapun yang tergolong sumber data sekunder yaitu : Ayat-ayat al-Quran, hadits, buku-buku tentang Akad Salam, buku-buku yang berhubungan dengan jual beli online.

Teknik Pengumpulan Data yakni membaca atau menelaah merupakan studi kepustakaan. Dengan metode ini diharapkan dapat diperoleh data mengenai Transaksi Akad salam dalam jual beli online.

Teknik Analisis Data, analisis data yang penulis gunakan adalah deskriptif kualitatif yaitu data yang berwujud kata-kata dan bukan rangkaian angka. Menurut Miles dan Huberman analisis data terdiri dari tiga tahap, yaitu (1) Data Reduction atau Reduksi Data adalah proses merangkum, memilih hal-hal yang pokok, memfokuskan pada hal-hal yang penting selanjutnya mencari tema dan polanya; (2) Data Display adalah penyajian yang dilakukan dalam bentuk uraian singkat, bagan,hubungan antar kategori, flow chart atau gambar; (3) Conclusion Drawing / Verification, kesimpulan awal dalam penelitian kualitatif masih bersifat sementara dan akan berubah bila terdapat bukti-bukti yang valid dan konsisten saat peneliti kembali ke lapangan maka kesimpulan tersebut kesimpulan yang kredible.

\section{PEMBAHASAN}

Internet atau International Networking merupakan hubungan dari dua computer atau lebih, bahkan sampai berjuta-juta computer (internasional) yang membentuk suatu jaringan yang dapat saling bertukar informasi. Internet menjanjikan kemudahan bagi penggunanya, melalui internet kita dapat memperoleh segala bentuk informasi dan komunikasi dari seluruh dunia, mulai dari informasi pendidikan, ekonomi, bursa saham, berita politik, bahan riset, periklanan, gaya hidup, hiburan, sampai acara ngobrol dan belanja.

Pada awalnya Internet digunakan untuk keperluan militer, yaitu pada masa perang dingin sekitar tahun 1969 di mana Departemen Pertahanan Amerika Serikat membutuhkan sebuah system jaringan yang menghubungkan semua computer di daerah vital untuk mengatasi sarangan nuklir. Untuk keperluan tersebut, Departemen Pertahanan Amerika Serikat melalui DARPA (Defense Advanced Research Projects Agency), bekerja sama dengan beberapa Universitas (University of California at Santa Barbara, University of California at Los Angeles, Standford Research Institute, University of Utah) membentuk ARPANET (Advanced Research Projects Administration).

Proyek ini awalnya hanya menghubungkan 3 komputer di California dan 1 di Utah, namun pada perkembangan selanjutnya banyak universitas di daerah tersebut yang ingin bergabung, sehingga diputuskan untuk mengklasifikasinya menjadi dua bagian, yaitu Sistem jaringan untuk Militer dan non Militer, gabungan keduanya disebut DARPA Internet yang akhirnya dikenal menjadi Internet saja.Untuk selanjutnya
Internet mulai berkembang pesat, merambah hampir seluruh bidang kehidupan. Di Indonesia sendiri Internet mulai dikenal luas sekitar tahun 1995.

Perkembangan Online Shopping di Indonesia sejalan dengan makin populernya Online Shopping di dunia pada saat ini. Toko Online di Indonesia baru mulai populer di tahun 2006. Pada akhir tahun 2008 jumlah toko Online di Indonesia meningkat puluhan hingga ratusan persen dari tahun sebelumnya. Factor pendukungnya adalah makin banyaknya pengguna internet di Indonesia, yang tadinya hanya sekitar 2.000 .000 orang pada tahun 2000 menjadi 25.000.000 pengguna pada tahun 2008 (internetworldstats.com, data hingga juni 2008). Factor kedua yang menyebabkan hal tersebut, karena semakin mudah dan murahnya koneksi internet di Indonesia, ketiga semakin banyak pendidikan dan pelatihan pembuatan toko online dengan harga sangat terjangkau.

Perkembangan online shopping atau belanja online seperti halnya laku.com, blibli.com, tokobagus.com, kini semakin ramai dengan berbagai jenis produk mulai dari fashion, makanan, keperluan rumah tangga, sampai gadget dll.Saat ini diperkirakan jumlah toko online di Indonesia telah berjumlah ratusan.

Semakin banyak e-commerce (layanan untuk sarana jual/beli online) yang berkembang di Indonesia membuat banyak perubahan pola belanja masyarakat yang awal bersifat konvensional kini berbelanja cukup dengan memilih produk yang ada di web/blog.Website depkominfo telah mempunyai halamam sistem informasi pemetaan e-commerce Indonesia, namun system tersebut belum berjalan sebagaimana mestinya. Beberapa toko online memiliki data web yang selalu terupdate dan memiliki informasi kontak yang jelas. Toko online lainnya ada yang datanta tidak update (informasi terakhir adalah data antara 1 bulan hingga 12 bulan sebelumnys), ada pula yang tidak memiliki informasi kontak secara jelas, dan fitur ecommerce yang tidak lengkap.

Saat ini diperkirakan jumlah toko online di Indonesia telah berjumlah ratusan. Menurut data statistik: jumlah masyarakat online di seluruh dunia (data tahun 2007) adalah 1,2 milyar dan diperkirakan bertumbuh menjadi 1,9 milyar pada tahun 2011 . Pertumbuhan pengguna internet yang amat pesat Nampak di seluruh benua, benua Asia tertinggi dari benua-benua lainnya. Data Jurnal Bisnis Internasional.Para pebisnis kecil yang menggunakan internet marketing bertumbuh $46 \%$ lebih cepat dibanding mereka yang belum menggunakan internet marketing. Media digital seperti internet telah merajai seluruh area bisnis dan komunikasi, mengalahkan media print (cetak). Toko online sangat indentik dengan UMKM, baik dari segi permodalan hingga manajemennya, brdanya hanya medianya saja, UMKM menganut media offline, sedangkan toko online menggunakan cara online. Namun satu hal yang cukup penting adalah belum adanya lembaga yang mewadahi dan mampu melindungu toko online Indonesia. Untuk komuniitas toko/bisnis online sendiri ada beberapa yang sudah terbentuk diharapkan dapat menumbuhkan bisnis online di Indonesia.

Shopee, aplikasi mobile commerce berbasis marketplace, akhirnya tiba di Indonesia pada hari ini, Selasa (1/12/2015). Aplikasi ini diklaim sebagai mobile marketplace pertama bagi konsumen-ke-konsumen ( $\mathrm{C} 2 \mathrm{C}$ ). Bagi yang belum tahu apa itu Shopee, aplikasi ini merupakan wadah belanja online yang lebih focus pada platform mobile sehingga orang - orang lebih mudah mencari, berbelanja, dan berjualan langsung di ponselnya saja. Shoppe dibesut oleh Garena, perusahaan yang ikenal sebagai publisher game Point Blank di Indonesia. 


\section{EKSISBANK Vol. 2 No. 2 Desember 2018}

Keputusan membuka cabang di Indonesia sendiri tak lepas dari potensi yang dipunyai Negara ini. CEO Shopee Chris Feng mengatakan Indonesia memiliki jumlah penduduk yang besar dengan angka 250 juta. Selain itu, penetrasi internet di Tanah air makin tinggi dengan lebih dari 80 juta pengguna Internet. "Indonesia memiliki pasar yang begitu besar. Bahkan tertinggi di Asia Tenggara. Kontribusi Indonesia mencapai 20-30\% dari total market Shopee," ujarnya saat ditemui di Hotel Mercure Sabang, Jakarta, Selasa (27/10/2015).

Shopee sendiri telah diluncurkan secara terbatas pada awal 2015 di kawasan Asia Tenggara , termasuk Singapura, Malaysia, Thailand, Vietnam, Filipina, Taiwan dan Indonesia. Platform ini menawarkan berbagai macam produk, dilengkapi dengan metode pembayaran yang aman, layanan pengiriman yang teregistrasi dan fitur sosial yang inovatif untuk menjadikan jual beli menjadi lebih menyenangkan, aman, dan praktis. Chief Executive officer Shoppe, Chris Feng, mengatakan bahwa Shopee merupakan platform belanja online yang mengusung konsep sosial dimana penggunanya tak hanya berfokus jual beli saja, tetapi juga bisa berinteraksi sesame pengguna lewat fitur pesan instan secara langsung. Menurut Chris, shopee ingin mendukung pertumbuhan Indonesia dalam e-commerce ritel global dengan membawa pengalaman berbelanja yang terintegrasi media sosial dan online shopping agar terjadi interaksi sosial antara penjual dan pembeli.

Menurut data yang disampaikan eMarketer dan Criteo State of Mobile Commerce pada September 2015 lalu, penjualan lewat perangkat mobile di Indonesia di kuartal ketiga tahun ini, telah mencapai 56 persen. Sedangkan penjualan global ecommerce di Indonesia diperkirakan meningkat sampai 64,3 persen di 2016 yang merupakan lonjakan persentase tertinggi di Dunia. Hal tersebut, diprediksi akan kembali melonjak sampai 2019. Selain itu, shopee juga berkomitmen untuk mengembangkan 'jiwa' kewirausahaan bagi para penjualnya. Sebagai informasi, para pengusaha diberdayakan untuk menjadi penjual yang lebih efektif dengan menyediakan akses kepada jutaan konsumen tanpa biaya dan dapat mengelola ketersediaan barang dan hubungan dengan pelanggan lebih baik. Saat ini, Shopee telah diunduh lebih dari 4 juta kali dan memiliki lebih dari 600 ribu pengikut. Anda bisa mengunduhnya secara gratis di App Store dan Google Play Store.

Mekanisme E-Commerce, transaksi elektronik antara emerchant (pihak yang menawarkan barang atau jasa melalui internet) dengan e-customer (pihak yang membeli barang atau jasa melalui internet) yang terjadi didunia maya atau di internet pada umumnya berlangsung secara paperlesstransaction, sedangkan dokumen yang digunakan dalam transaksi tersebut bukanlah paper document, melainkan dokumen elektronik (digital document). Kontrak on-line dalam e-commerce meurut Santiago Cavanillas dan A. Martines Nadal, seperti oleh Arsyad Sanusi memiliki banyak tipe dan variasi, yaitu Kontrak melalui chatting dan video coference; kontrak melaui e-mail; kontrak melalui web atau situs; Chatting dan Video Conference adalah komunikasi yang disediakan oleh internet yang biasa digunakan untuk dialog interaktif secara langsung. Dengan chatting seseorang dapat berkomunikasi secara langsung dengan orang lain persis seperti telepon, hanya saja komunikasi lewat chatting ini adalah tulisan atau pernyataan yang terbaca pada computer masing-masing.
Sesuai dengan namanya, video conference adalah alat untuk berbicara dengan beberapa pihak dengan melihat gambar dan mendengar suara secara langsung pihak yang dihubungi dengan alat ini. Dengan demikian melakukan kontrak dengan menggunakan jasa chatting dan video conference ini dapat dilakukan secara kangsung antara beberapa pihak dengan menggunakan sarana computer atau televisi.

Kontrak melalui e-mail adalah salah satu kontrak on-line yang sangat popular karena pengguna e-mail saat ini sangat banyak dan mendunia dengan biaya yang sangat murah dan waktu yang efesien. Untuk memperoleh alamat e-mail dapat dilakukan dengan cara mendaftarkan diri kepada penyedia layanan e-mail gratis atau mendaftarkan diri sebagai subscriber pada server atau ISP tertentu. Kontrak e-mail dapat berupa penawaran yang dikirimkan kepada seseorang atau kepada banyak orang yang tergabung dalam sebuah mailing list, serta penerimaan dan pemberitahuan penerimaan yang seluruhnya dikirimkan melalui e-mail. Di samping itu kontrak e-mail dapat dilakukan dengan penawaran barangnya diberikan melalui situs web yang memposting penawarannya, sedangkan penerimaannya dilakukan melalui e-mail.

Kontak melaui web dapat dilakukan dengan cara web seorang supplier (baik yang berlokasi di server supplier maupun diletakkan pada server pihak ketiga) memiliki diskripsi produk atau jasa dan satu seri halaman yang bersifat selfcontraction, yaitu dapat digunakan untuk membuat kontrak sendiri, yang memungkinkan pengunjung web untuk memesan produk atau jasa tersebut. Para konsumen harus menyediakan informasi personal harus menyertakan nomor kartu kredit. Sebagai contoh dalam melakukan transaksi jual beli online di situs jual beli Shopee, mekanismenya adalah sebagai berikut: (1) Untuk produk on-line yang berupa software, pembeli diizinkan untuk men-download-nya; (2) Untuk produk yang berwujud fisik, pengiriman barang dilakukan sampai di rumah konsumen; (3) Untuk pembelian jasa, supplier menyediakan untuk melayani konsumen sesuai dengan yang telah ditentukan dalam perjanjian.

Mekanisme transkasi elektronik dengan e-commerce dimulai dengan adanya penawaran suatu produk tertentu oleh penjual (misalnya bertempat kedudukan di USA) di suatu website melalui server yang berada di Indonesia (misalnya detik.com). Apabila konsumen tersebut akan mengisi order mail yang telah disediakan oleh pihak penjual. Jika pembeli ingin membayar untuk barang yang telah dipilih, ia harus mengisi form transaksi. Biasanya form ini menanyakan identitas pembeli serta nomor kartu kredit. Karena informasi ini bisa disalahgunakan jika jatuh ke tangan yang salah, maka pihak penyedia jasa e-commerce telah mengusahakan agar pengiriman data-data tersebut berjalan secara aman, dengan menggunakan standar security tertentu. Setelah pembeli mengadakan transaksi, retailer akan mengirimkan barang yang dipesan melalui jasa pos langsung ke rumah pembeli. Beberapa cybershop menyediakan fasilitas bagi pembeli untuk mengecek status barang yang telah dikirim melalui internet.

Sebagai contoh beberapa cara dalam melakukan transaksi di aplikasi shoope: (1) Silahkan download terlebih dahulu aplikasi Shoope pada ponsel anda; (2) Kemudian login terlebih dahulu, apabila belum mempunyai account Anda harus mendaftar terlebih dahulu; (3) Setelah membuat account, pilih produk yang akan anda beli. Sebagai contoh anda akan membeli produk celana pelangsing akan muncul tampilan sebagai berikut: 


\section{Gambar 3.1}

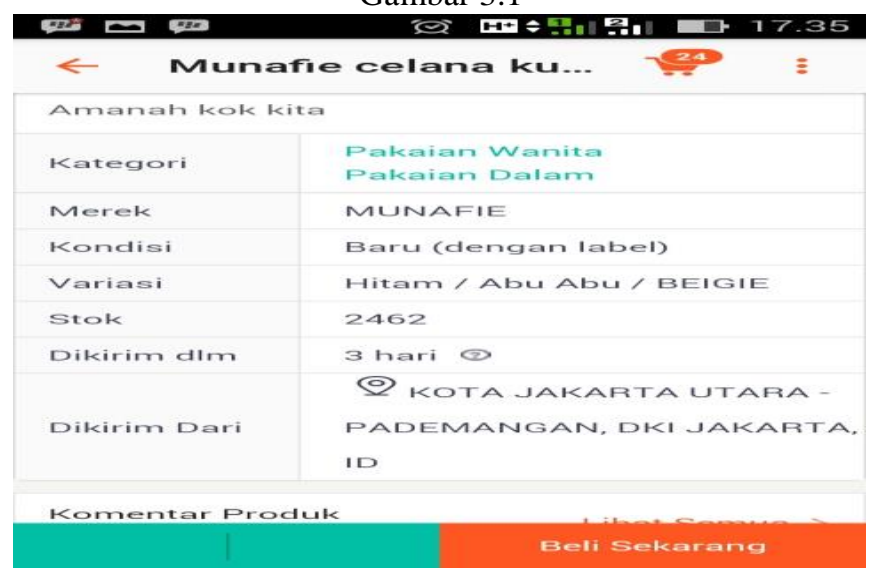

Kemudian klik pada kolom Pojok kanan bawah ( Beli sekarang). Akan muncul tampilan sebagai berikut:

Gambar 3.2

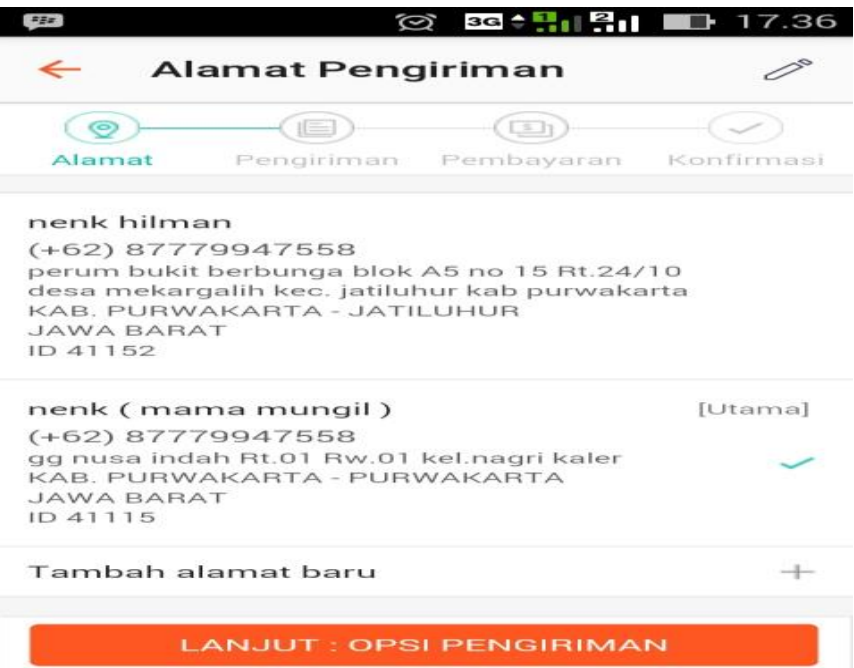

Setelah lanjut ke opsi pengiriman anda akan diminta melakukan pembayaran, dengan tampilan sebagai berikut:

Gambar 3.3

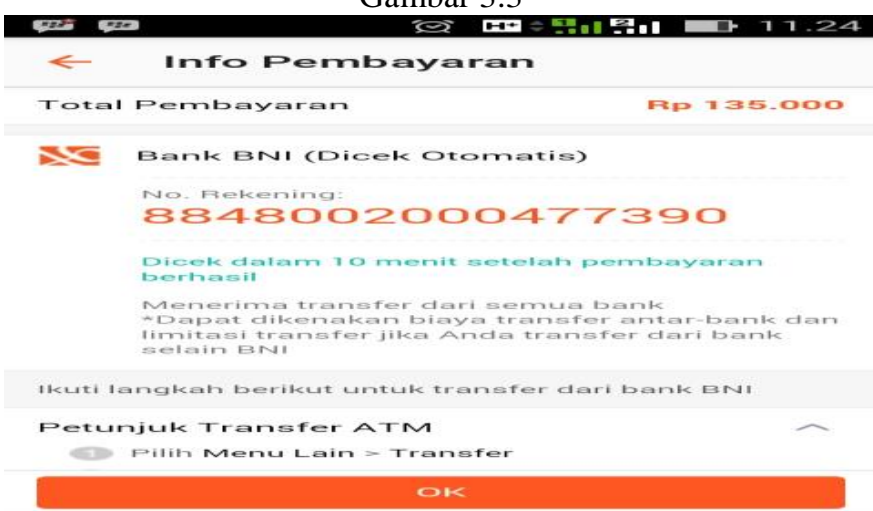

Lalu tekan Ok. Pembayaran akan dikonfirmasi setelah 10 menit. Anda tinggal menunggu notifikasi bahwa pembayaran telah selesai dikonfirmasi.

Apabila sudah menerima notifikasi pembayaran anda hanyya tinggal menunggu barang pesanan anda dikirimkan dalam batas waktu yang telah ditentukan, apabila barang belum sampai hingga batas yang telah ditentukan anda bisa mengajuka klaim pengembalian uang pada aplikasi tersebut.

Apabila barang telah sampai silahkan klik pada kolom dibawah ini:

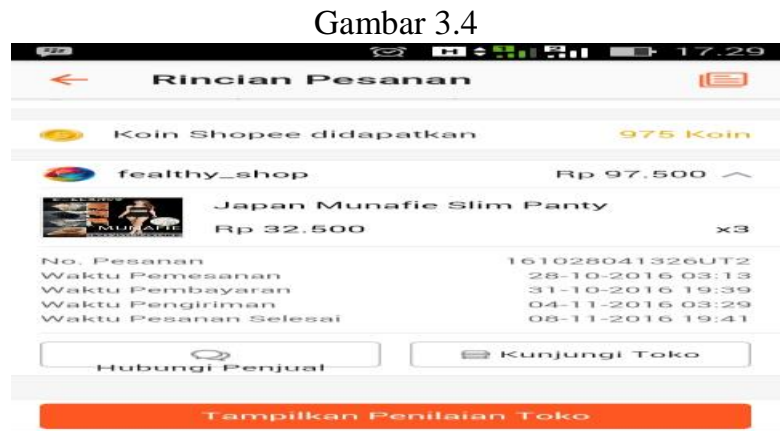

Sehingga penjual bisa mencairkan dana pembelian dari brtang yang telah anda beli. Selesai. Anda telah melakukan transaksi pembelian online dengan aplikasi Shoope tersebut.

Dari mekanisme tersebut dapat simpulkan bahwa dalam jual beli secara tersebut sangatlah mudah, karena pembeli tidak perlu membuang waktu untuk mendapatkan barang yang diinginkan. Hanya menggunakan ponsel saja pembeli sudah bisa bertransaksi dengan aman dan nyaman.

Hukum Islam Seputar E-Commerce, berdasarkan uraian fakta diatas, bisa digarisbawahi, bahwa transaksi perdagangan melalui e-commerce ini bisa dideskripsikan sebagai berikut:

1. Penjual dan pembeli tidak berada pada satu tempat yang sama, bisa dalam kota, wilayah atau Negara yang berbeda;

2. Konsekuensi dari poin pertama, maka fisik barang yang diperjualbelikan dalam transaksi e-commerce ini tidak ada pada satu tempat, dimana penjual dan pembeli bertemu. Kalaupun ada, barang tersebut hanya berupa image, bisa foto atau film yang ditunjukan kepada pembeli sebelum terjadinya transaksi jual-beli;

3. Pembayaran dilakukan oleh pembeli di depan secara tunai, bukan di hutang, baru kemudian barang akan dikirim oleh penjual kepada pembeli;

4. Alat pembayaran yang digunakan adalah uang yang di transfer melalui kartu kredit atau, kartu debit atau smartcard.

Berdasarkan fakta-fakta di atas, maka bisa disimpulkan bahwa hukum yang berlaku terkait dengan transaksi ecommerce ini tidak bisa dilepaskan dari hukum jual-beli jarak jauh, salam, salaf, hawalah, dan penggunaan uang elektronik.

Hukum Islam tentang Jual Beli Jarak Jauh, dalam melakukan transaksi jaul beli, tenunya harus diperhatikan rukun maupun syaratnya, agar transaksi tersebut menjadi halal hukumnya. Begitu pun dengan transaksi jual beli online, tanpa memperhatikan rukun dan syarat, maka ditakutkan transaksi jual beli online tersebut menjadi haram hukumnya.

Jual beli jarak jauh adalah pertukaran harta dengan harta dalam bentuk pemindahan pemilikan atau kondisi, dimana keberadaan penjual dan pembeli di dua tempat berbeda. Sebagaimana dalam ketentuan jual beli secara umum, syariat telah menjadikan faktor suka sama suka sebagai syarat mendasar bagi akad jual beli. Suka sama suka bisa terjadi ketika penjual dan pembeli ada di satu tempat yang sama, dan bisa juga terjadi meski pembeli berada di dua tempat yang berbeda.

Karena itu, tempat tidak menghalangi terjadinya pertemuan ijab dan qabul. Kondisi ketika suka sama suka (at-taradhi) antara penjual dan pembeli tadi terjadi, dan pertemuan ijab dan qabul juga terjadi di majelis akad. Jual beli jarak jauh ini, baik dengan menggunakan telepon, faks, teleks, internet, dan sebagainya, pada dasarnya memiliki hukum yang sama dengan jual beli pada satu tempat yang sama. Ada riwayat dari Rasul SAW yang mengisyaratkan hal ini. Dari Anas RA : "Sebelum wafat, Nabi SAW menulis surat kepada Kisra,kaisar, najasyi 
dan kepada setiap dictator, untuk mengajak mereka menyembah Allah,'(Shahih at-tirmidzi)

Dalam hadis ini ada dalalah yang jelas, bahwa seruan kepada Allah dari jarak jauh dama dengan seruan seseorang kepada orang yang berada di tempat yang sama. Andai saja seruan dari jarak jauh itu tidak bisa dihukumi tabligh (menyampaikan secara langsung), dan tidak bisa dijadikan hujjah (bagi Nabi di hadapan Allah), niscaya Rasul SAW tidak akan melakukannya guna menyampaikan risalah dan menegakan hujjah terhadap setiap dictator itu. Karena itu, hadits ini mengisyaratkan, bahwa akad jual beli dari jarak jauh yang memenuhi syaratsyarat jual beli adalah sama hukumnya dengan akad jual beli dimana penjual dan pembelinya berada di satu tempat yang sama. Jika jual beli ini terjadi melalui media tulisan atau elektronik, maka akad tersebut dinyatakan sah begitu ada pernyataan qabul sebelum orang yang menyampaikan penawaran (al-mujib) menarik penawarannya, dengan syarat orang yang menyampaikan ijab (penawaran) tersebut mengetahui qabul-nya.

Dengan demikian, terjadinya pertemuan antara kehendak penjual dan pembeli untuk melangsungkan jual beli dari jarak jauh, sama hukumnya dengan pertemuan antara kehendak penjual dan pembeli di satu tempat yang sama. Fakta jual beli jarak jauh ini berlaku untuk jual beli yang menggunakan teleks, faxs, surat elektronik, atau yang dikenal dengan istilah ecommerce atau e-business. Akad dalam transaksi e-commerce ini mengikat penjual dan pembeli, begitu keluar dan qabul-nya dinyatakan, baik orang yang menyampaikan penawaran (almujib) atau menyatakan ijab tadi mengetahui qabul-nya atau tidak.Kecuali, pihak yang menawarkan ijab (penawaran) tadi menarik penawaran (ijab)-nya sebelum akad tersebut mengikat.Karena itu, tempat akad adalah tempat seseorang yang menyatakan qabul tadi. Atas dasar itu, maka ststus khiyar majelis tetap berlaku sampai orang yang menyatakan qabul tadi meninggalkan tempat qabul-nya.

Al- Kasani berkata, "sedangkan (ijab dan qabul melalui) pesan, gambarannya adalah mengirim utusan kepada seseorang, lalu dia berkata kepada utusan itu, "Aku jual hamba sahayaku ini kepada Fulan yang tidak ada di tempat ini, dengan harga sekian, jadi pergilah kepadanya... Lalu, utusan itu pergi dan menyampaikan pesan tadi.Setelah itu, pembelinya berkata di majelis (qabul), "saya terima."maka, jual beli seperti ini sah." Dalam kitab al-majmu' dinyatakan, "jika kita katakana sah (jual beli melalui tulisan), maka syaratnya adalah orang yang diberi tulisan itu menerima, begitu dia melihat tulisan tersebut.Itu yang lebih sahih." Kemudian penulis kitab alMajmu' ini berkata, "sebagian ulama mazhab kami (Syafii) berpendapat sebagai pendetilan atas keabsahan jual beli melalui tulisan tersebut. Seandainya dia berkata, "Aku jual rumahku kepada Fulan, sementara si Fulan tidak ada di tempat, maka ketika berita itu sampai kepada si Fulan ini, lalu dia menyatakan, "aku terima", maka jual beli tersebut sah." Apa yang dinyatakan dalam penjelasan al-Kasai juaga apa yang dinyatakan dalam kitab al-Majmu' jelas menyatakan, bahwa akad antara penjual dan pembeli ketika keduanya berada di dua tempat yang berbeda jelas sah begitu pernyaraan qabul-nya dinyatakan.Juga tidak ada syarat, bahwa pihak yang menyatakan ijab (penawaran) tersebut mengetahui ucapan pihak yang menyatakan qabul tadi.

Menurut Fatwa Dewan Syariah Nasional No: 05/DSNMUI/IV/2000 tentang jual beli salam yang ditetapkan di Jakarta, 29 Dzulhijjah 1420 H/4 April 2000 M. Tentang ketentuan pembayaran, ketentuan tentang barang, ketentuan tentang salam, tentang penyerahan barang sebelum atau pada waktunya, tentang pembatalan kontrak, tentang perselisihan dalam transaksi salam pada jual beli online.

Penjelasan di atas, maka transakasi dilakukan melalui ecommerce atau e-business ini, secara syar'I jelas sah. Ini dilihat dari aspek terjadinya ijab dan qabul. Adapun dari aspek lain, yaitu konsekuensi tidak adanya penjual dan pembeli di satu tempat yang sama, yang menyebabkan barang yang dijual tersebut menjadi dzimmah maushufah (tanggungan yang dideskripsikan), baik dalam bentuk image, film atau yang lain, maka status transaksi e-commerce ini sama dengan jual beli Salam. Jadi salam adalah bagian dari jual beli, maka di dalamnya berlaku syarat dan ketentuan yang sama dengan jual beli secara umum. Namun, di dalamnya ditambahkan beberapa hukum, yang khusus untuk salam.Misalnya, didahulukannya pembayaran harga di majelis akad. Ibn Hajar berkata, "Mereka sepakat, bahwa untuk salam itu disyaratkan apa ssaja yang disyaratkan untuk jual beli." Ibn Qudamah berkata tentang salam, "salam adalah salah satu jenis jual beli. Salam dilakukan dengan apa saja yang digunakan untuk mengakadkan jual beli, dengan lafadz salam atau salaf. Di dalamnya diakui sejumlah syarat yang juga diakui dalam jual beli."

Berdasarkan manath hukum jual beli Salam di atas, bisa disimpulkan bahwa fakta E-Commerce atau E-Business merupakan fakta jual beli Salam, dimana penjual dan pembeli bertemu dalam majelis akad, tetapi karena faktor jarak yang jauh, maka barang yang ditawarkan kepada pembeli tidak langsung diserahterimakan. Dengan kata lain, barang yang hendak dijual melalui internet tersebut merupakan dzimmah maushufah (tanggungan yang) di tangan penjualnya. Karena, yang ditunjukan kepada pembelinya adalah image (gambar) atau film barang tersebut. Selain itu, syarat pembayaran di depan dalam setiap transaksi jual beli melalui e-commerce ini juga merupakan syarat yang berlaku dalam jual beli Salam.

Hukum Salam dan Salaf, jual-beli Salam adalah jual beli barang yang dideskripsikan berada dalam tanggungan.Salam juga merupakan bentuk jual-beli dengan menyerahkan alat tukar pada saat ini untuk kompensasi yang di deskripsikan berada dalam tanggungan sampai tempo tertentu.

Imam an-Nawawi mengatakan, "Tentang alam mereka menyebutkan berbagai ungkapan. Yang paling baik adalah bahwa salam itu merupakan akad terhadap sesuatu yang dideskripsikan dalam tanggungan dengan kompensasi yang diberikan segera. Disebut salam, karena penyerahan harga terjadi di majelis akad, dan disebut salaf karena harganya dibayarkan dahulu". Salam adalah istilah penduduk Hijaz, sedangkan salaf merupakan istilah penduduk Irak. Salam ini legal (masyru') berdasarkan firman Allah SWT:

\section{وَأَحَلَّ اللهُ الْبَيْعَ}

"Padahal Allah telah menghalalkan jual beli." (QS alBaqarah [2]: 275)

Jual beli di dalam ayat ini juga mencakup salam, karena salam merupakan salah satu bentuk jual beli. Legalitas salam juga ditunjukkan oleh firman Allah SWT:

Hai orang-orang yang beriman, apabila kamu bermu'amalah tidak secara tunai untuk waktu yang ditentukan, hendaklah kamu menuliskannya.

\section{KESIMPULAN}

Berdasarkan pada pembahasan sebelumnya, dan merujuk pada hasil penelitian yang telah dilakukan maka dapat disimpulkan hal-hal berikut: 


\section{EKSISBANK Vol. 2 No. 2 Desember 2018}

1. Skema akad salam dalam jual beli online terdapat muslam (pembeli), muslam ilaih (penjual), muslam fihi (objek barang) dan juga sighat (ijab dan qabul).

2. Akad salam dalam jual beli online, telah memenuhi rukun dan syarat sah yang berlaku dalam hukum fiqh, dan sesuai fatwa DSN MUI tahun 2000. Melihat dari proses dan skema akad salam dalam jual beli online ini adalah bentuk yang diperbolehkan.

3. Mekanisme dalam transaksi akad salam pada jual beli online ini memudahkan para konsumen dalam melakukan transaksi secara online.

\section{REFERENSI}

[1] Abdurrahman Hafidz, (2012) Bisnis Online Halal atau Haram, Al-Azhar press, Bogor.

[2] Adi Nugroho, (2006), E-commerce Memahami Perdagangan di Dunia Maya, Informatika, Bandung.

[3] Al-Juhailli Wahbah, (1989), AlFiqh Al-Islami wa Adillatuh, Dar AlFikr, Damsyik.

[4] Al-Kasani 'Alauddin, (1996), Badai' Ash-Shanai' fi Tartib Asy-Syarai', Dar Al-Fikr, Beirut.

[5] A. Zakaria, (2012), Etika Bisnis Dalam Islam, Ibn Azka Press.

[6] Barkatulloh dan Teguh Prasetyo, (2005), Bisnis E-commerce: Studi Sistem Keamanan dan Hukum di Indonesia, Pustaka Pelajar, Yogyakarta.

[7] Billah Mohd Ma'sum, (2010) Islamic E-commerce terapan: Tinjauan Hukaum dan praktek, sweet\& Maxwell Asia, Malaysia.

[8] Boedi Abdulah, (2013) Ekonomi Mikro Islam, Pustaka setia, Bandung.

[9] Ehas Astrid, (2007), Internet, Ercontara rajawali, Jakarta.

[10] Kamaluddin, Muhammad bin Abdul-Wahid bin Hammam,syarah Fath Al-Qadir, Dar Al-Fikr, Beirut.

[11] Muslich Ahmad wardi (2010), Fiqh Muamalat, Amzah, Jakarta.

[12] Miles, Matthew B.,dkk, (2007), Analisis Data Kualitatif: Buku Sumber Tentang Metode-metode Baru. UI Press, Jakarta.

[13] Muhammad bin Ismail Al-Kahlani, Subul As-Salam, Juz 3, Maktabah Mushthafa Al-Babiy Al-Halabiy, Mesir, cet. IV, 1960, hlm. 49.
[14] Noor Juliansyah, (2011), Metodologi penelitian, kencana, Jakarta.

[15] Onno W.Purbo dan Aang Arif Wahyudi, (2000) Mengenal E-commerce, Elex Media Komputindo, Jakarta.

[16] Suhendi Hendi, (2011), Fiqh Muamalah, raja Grafindo persada, Jakarta.

[17] Syafe'I Rachmat, Fiqh Muamalah, Pustaka Setia, Bandung.

[18] Syafi'I Muhammad Antonio (2001), Bank Syariah Dari Teori ke Praktik, Tazkia Cendikia, Jakarta.

[19] Penelitian mennurut Lisda Apriliani ( 2012) yang berjudul Jual Beli Dengan Sistem Al-Bai'u Salam Dalam Pembiayaan Sariah Di Indonesia. Skripsi. Tidak diterbitkan.

[20] Penelitian menurut Rahmat Anwar Ferdian (2013) dengan judul Tinjauan Hukum Islam Terhadap Jual Beli Dengan Model Periklanan Website Tokobagus.Com. Skripsi. Tidak diterbitkan.

[21] Penelitian menurut Biuty Wulan octavia (2011) Tinjauan Hukum Islam Terhadap Jual Beli Akad As-Salam Dengan Sistem On Line Di Pand's Collection Pandaranan. Skripsi. Tidak diterbitkan.

[22] Bambang H, "Internet and E-commerce", artikel diakses pada 24 oktober 2016 dari http:/bambanghermawan.ilearning.me/2014/07/01/89/

[23] http://tekno.liputan6.com/read/2323611/10-situs-e-commerce-palinglaris-bukalapakcom-nomor-1 di akses pada. 7 agustus 2016 at 2:52 pm

[24] https://rahmatwibowo4.blogspot.com/2016/04/10-situs-indonesiadengan-pendapatan.html 7 agustus 2016 at $2.59 \mathrm{pm}$.

[25] http://slideplayer.info/slide/2776669/ (di akses pada 22 agustus 2016. $10.22 \mathrm{Wib})$

[26] http://pengertiandefinisi.com/pengertian-transaksi-buku-transaksi-danjenis/ (26 agustus 2016. 17.38 WIB)

[27] Lorena Triasisca, "E-commerce dan E-Businnes" artikel diakses pada 15 oktober 2016 dari http://renaisca.wordpress.com/makalah-pti2/makalah-pti/bab-ii-pembahasan/e-commerce-dan-e-business/

[28] Rifaun Naim, "Kelebihan dan Kekurangan E-commerce" artikel diambil pada tanggal 17

[29] September 2014 http://buahilmu.wordpress.com/2010/10/30/keuntungan-dankekurangan-E-commerce/

[30] www.szeretlek-87.weebly.com di akses pada hari senin 14 november 2016 pada jam 09:30. 